\title{
Adenoid Basal Cell Carcinoma Presenting as Ulceroproliferative Nodule Nose: A Rare Histopathological Variant
}

\author{
Megha Ralli*1, Pinki Pandey ${ }^{1}$, Savita Agarwal $^{1}$ and Jitendra Chauhan ${ }^{2}$ \\ ${ }^{1}$ Department of Pathology, UP University of Medical Sciences, Etawah, India
}

${ }^{2}$ Department of Otorhinolaryngology, UP University of Medical Sciences, Etawah, India

Received: January 06, 2018; Published: January 16, 2018

*Corresponding author: Megha Ralli, Departments of Pathology, UP University of Medical Sciences , Saifai, Etawah, 206130 India.

\begin{abstract}
Basal cell carcinomas (BCCs), the most common non-melanocytic neoplasm, display a considerable variety of appearances under light microscope as well as in clinical practice. BCCs can exhibit both a variety of histological growth patterns namely; superficial, nodular, micronodular or infiltrating and histological differentiation towards the cutaneous appendages, such as adenoid, keratotic, sebaceous, basosquamous/metatypical, pilar, apocrine, eccrine or fibroepithelial, adamantinoid, giant cell, morphoeiform, pigmented, clear-cell, signet ring cell. Adenoid basal cell carcinoma, a rare variant of basal cell carcinoma characterized by a specific histologic appearance, has been sparingly described and reports have been primarily limited to case series with limited data and only 12 cases have been reported in the English literature. An attempt is made to document the histological features of adenoid variant of BCC in a 65-year-old male, who presented with a slow growing ulceroproliferative lesion on nose. The case is being reported because of its rarity and to contribute in the spectrum of basal cell carcinomas.
\end{abstract}

Keywords: Adenoid; Basal Cell Carcinoma; Nose; Histopathology; Differentiation

\section{Introduction}

Basal cell carcinoma (BCC) is the most common non-melanocytic neoplasm, accounting for approximately $70 \%$ of all malignant diseases of skin [1]. It occurs predominantly in men after the fourth decade of life with peak incidence at 6 th decade [2]. It is exclusively seen on sun exposed sites such as face and neck (80-90\%). About one-third of BCC occur in non-sun exposed areas like axilla, groin, buttocks, nipple, breast, penis and scrotum [2]. It is derived from basaloid epithelia located in the follicular bulges, the anagen hair bulb, the follicular matrix cells and specific basaloid cells of the interfollicular epidermis [3]. The clinical appearance of BCC is as variable as its histologic patterns; ranging from a papulonodular lesion with a pearly transluscent edge, erythematous plaque with visible telangiectasia to an ulcerated destructive lesion ('rodent ulcer') [1]. It is a slow-growing, relatively non-aggressive tumor with well known variability in morphology. Adenoid type of BCC is one of the rare histopathological variant of BCC which has not found to have any site predilection. The case is being reported because of its extreme rarity as per the literature published worldwide. Relevant resources were identified by a Pubmed/Medline search for databases from January 1950 to January 2016 using the keywords basal cell, carcinoma differentiation, adenoid, rare histopathological variant, and sunlight. A total of twelve papers were identified [414]. An attempt is made to document the histological features of adenoid variant of BCC in a 65-year-old male, who presented with a slow growing ulceroproliferative lesion on nose.

\section{Case Summary}

A 65 years old male presented to the ENT department with a slow growing ulceroproliferative nodule involving the tip and upper surface of nose since 2 years. The lesion started as an asymptomatic raised lesion on the normal skin of nose evolving into a non-healing ulcer eventually over a period of six months. The patient was farmer by profession, which involved long hours of sun exposure. There was no previous personal history of skin cancer, and no other significant cutaneous or medical history was elicited. Notably, he had no history of trauma, chronic inflammation, immune deficiency, or exposure to artificial ionizing radiation or arsenic. Family members did not report similar skin conditions. The patient did not seek early medical help because of his low social milieu and a low level of knowledge about skin tumors. On 
clinical examination, it was an ulcerated lesion of about $3 \times 4 \mathrm{~cm}$ with crusting, rolled out indurated edges and sloping margins (Figure 1). The floor was sloughed out with serosanguinous discharge. There was no evidence of lymphadenopathy and his general physical condition was stable. Laboratory studies, including a complete blood cell count, blood chemistry and urine analysis, were within normal limits. No evidence of metastases was found with a total body computed tomography scan.

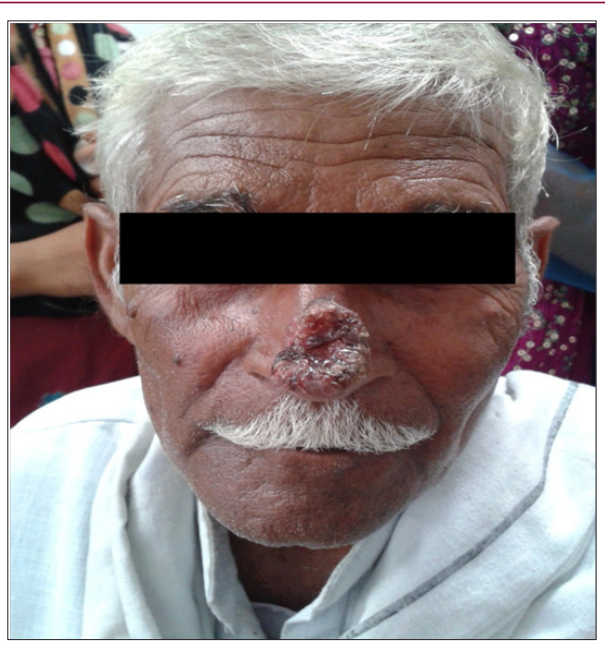

Figure 1: Ulceroproliferative nodule with crusting, rolled out indurated edges and sloping margins.

With the clinical diagnosis of BCC, the patient underwent a wide local excision of the ulcerated nodular mass and sent for histopathological examination. Grossly received a grayish brown raised nodule with a thin rim of skin at the periphery, measuring $2 \times 3 \mathrm{~cm}$. Histopathological examination showed a focally ulcerated epidermal lining and invasion of the deeper dermis. The tumor predominantly displayed an adenoid pattern with many tubules and few cystically dilated spaces containing amorphous, granular material. In some areas, the adenoid pattern coexisted with cells arranged in characteristic intertwining strands and radially around the islands of connective tissue, resulting in a tumor with a lace-like pattern (Figures 2 \& 3). Peripheral palisading of the basaloid cells was seen in some of the islands along with retraction artifact of the surrounding stroma and connection to the overlying epidermis was evident. A diagnosis of basal cell carcinoma, adenoid subtype, was rendered. Postoperative recovery was uneventful. The patient is under close follow up, and has shown no evidence of recurrence in the ten months following treatment.

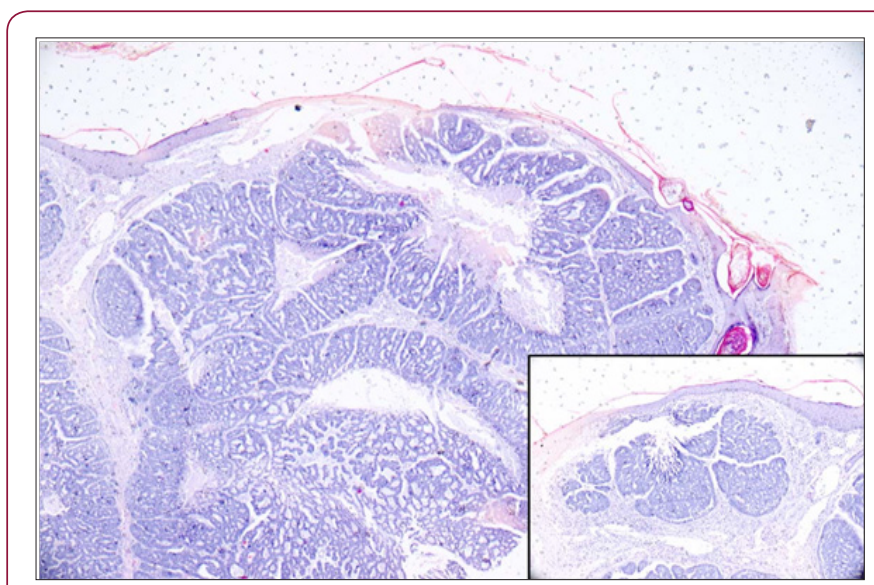

Figure 2: Photomicrograph showing nodules of basaloid cells exhibiting adenoid pattern localized in reticular dermis. Inset: Note the continuity with the epidermis $(\mathrm{H}$ \& E, X40; Inset: H \& E, X 40).

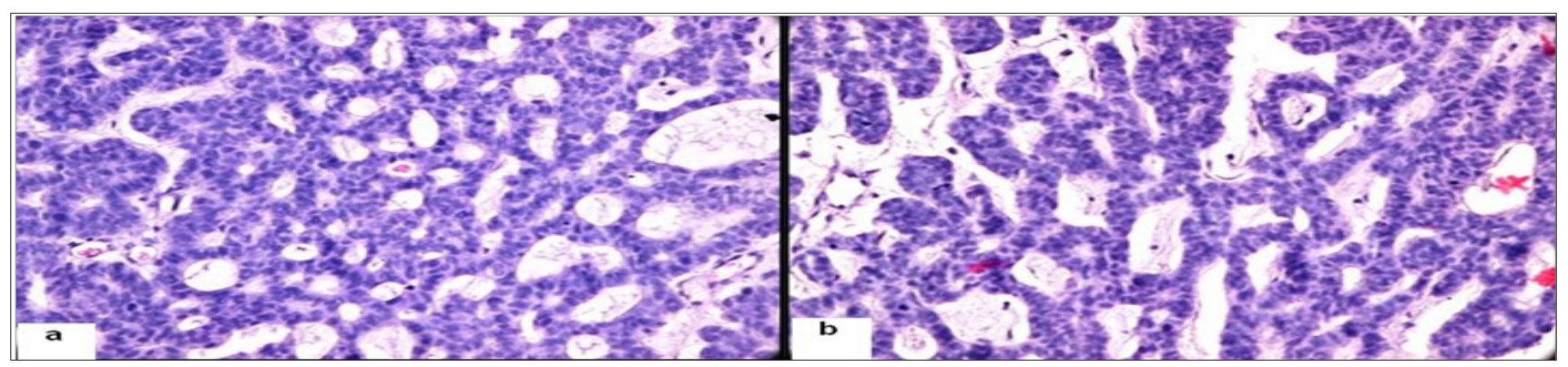

Figure 3: Photomicrograph showing a) adenoid pattern with many tubules and few cystically dilated spaces containing amorphous, granular material ( $\mathrm{H} \& \mathrm{E}, \mathrm{X} 400)$; b) tubular differentiation with intertwining strands of epithelial cells forming lacelike pattern and spaces filled with mucoid material (H \& E, X 400).

\section{Discussion}

Basal cell carcinomas display a considerable variety of appearances under light microscope as well as in clinical practice BCC is an epithelial malignant tumour with a low malignant potential, consisting of cells which look like the basal epidermis layer. The multiple variants of BCC share the common histological features of lobules, columns, bands and cords of basaloid cells (germinative cells), peripheral palisading of lesional cell nuclei, a specialized stroma, and clefting artifact between the epidermis and the stroma $[15,16]$. Histological diagnostics and classification of BCCs are essential for an assessment of the percentage proportions of particular histological groups, risk determination of the recurrence of this illness and comparison of treatment results $[17,18]$. There is no unified and generally accepted classification of BCCs. Most authors use two basic criteria in the creation of classifications of histological types, the histological growth pattern and histological differentiation. BCCs can exhibit both a variety of growth patterns namely; superficial, nodular, micronodular or infiltrating and a variety of types of differentiation towards the cutaneous appendages, such as adenoid, keratotic, 
sebaceous, basosquamous/metatypical, pilar, apocrine, eccrine or fibroepithelial, adamantinoid, giant cell, morphoeiform, pigmented, clear-cell, signet ring cell $[15,16,19]$.

Adenoid type of BCC is a rare histopathological variant, often regarded as a low grade malignancy compared to other high grade subtypes like nodular and morpheic form. There is paucity of literature on exact incidence of adenoid BCC but Bastiaens. Reported the incidence of $1.3 \%$ [20]. Ultraviolet radiation is considered the single most important risk factor for BCC. Additional risk factors include arsenic, coal tar derivatives, irradiation, scars, burn sites, chronic inflammation, ulcer and immune deficiency [3]. Genetic syndromes such as xeroderma pigmentosa and basal cell nevus syndrome are also associated with occurrence of BCC [21].
In our case, no such risk factors or genodermatoses were found. Adenoid type of BCC is a rare histopathological variant which can morphologically present as pigmented and nonpigmented nodule or ulcer without any site predilection. Adenoid BCC has been reported at various sites including axillae, $[5,8,11]$ back, $[6,7,12]$ inner canthus of eye, [4,14] chin [9] and melolabial fold [10]. Akin to our case, the case reported by Jetley [13] had same location on the nose and both the cases revealed same histology of adenoid type of BCC (Table 1) [13]. Histopathology of this rare variant of basal cell carcinoma with eccrine differentiation (adenoid) shows arrangement of cells in the intertwining strands and radially around islands of connective tissue, resulting in a tumor with a lace like pattern.

Table 1: Summary of 13 reported cases of adenoid basal cell carcinoma with varied clinical presentations.

\begin{tabular}{|c|c|c|c|c|c|c|c|c|}
\hline S.No & Authors & Year & Total cases & Age (years) & Sex & Site & Size $(\mathrm{cm})$ & $\begin{array}{c}\text { Clinical } \\
\text { presentation }\end{array}$ \\
\hline 1. & $\begin{array}{c}\text { Copcu et al. } \\
{[4]}\end{array}$ & 2005 & 1 & 62 & $\mathrm{~F}$ & $\begin{array}{l}\text { Inner canthus } \\
\text { of right eye }\end{array}$ & $5.5 \times 4.5$ & Exophytic growth \\
\hline 2. & Niwa et al. [5] & 2006 & 1 & 56 & M & Axilla right & $\begin{array}{c}2 \mathrm{~cm} \mathrm{in} \\
\text { diameter }\end{array}$ & Papulonodular lesion \\
\hline 3. & $\begin{array}{c}\text { Cohen et al. } \\
{[6]}\end{array}$ & 2006 & 1 & Adult & $\mathrm{M}$ & Lower back & $18 \times 30$ & Ulcerative lesion \\
\hline 4. & $\begin{array}{c}\text { Fresini et al. } \\
\text { [7] }\end{array}$ & 2007 & 1 & 72 & M & Back & $30 \times 20$ & $\begin{array}{c}\text { Vegetative mass with } \\
\text { ulceration }\end{array}$ \\
\hline 5. & Kim et al. [8] & 2008 & 1 & 33 & $\mathrm{~F}$ & Axilla & $1 \times 0.8 \times 1.5$ & Nodule \\
\hline 6. & $\begin{array}{l}\text { Mehta et al. } \\
{[9]}\end{array}$ & 2009 & 1 & 85 & $\mathrm{~F}$ & Chin & $3 \times 4$ & Pigmented nodule \\
\hline 7. & $\begin{array}{l}\text { Golda et al. } \\
\quad[10]\end{array}$ & 2009 & 1 & 70 & M & $\begin{array}{l}\text { Melolabial } \\
\text { fold right }\end{array}$ & $2 \times 1$ & Nodule \\
\hline 8. & $\begin{array}{c}\text { Wani et al. } \\
\text { [11] }\end{array}$ & 2012 & 1 & 35 & M & Axilla right & $8 \times 5$ & $\begin{array}{l}\text { Vegetative ulcerative } \\
\text { growth }\end{array}$ \\
\hline 9. & $\begin{array}{c}\text { Tambe et al. } \\
\text { [12] }\end{array}$ & 2013 & 2 & $\begin{array}{l}56 \\
60\end{array}$ & $\begin{array}{l}\mathrm{F} \\
\mathrm{F}\end{array}$ & $\begin{array}{l}\text { Lower back } \\
\text { Lower back }\end{array}$ & $\begin{array}{c}3 \times 4 \\
3 \times 2.5\end{array}$ & $\begin{array}{l}\text { Pigmented nodule } \\
\text { Ulcerated lesion }\end{array}$ \\
\hline 10. & $\begin{array}{c}\text { Jetley et al. } \\
\text { [13] }\end{array}$ & 2013 & 1 & 55 & M & $\begin{array}{l}\text { Nose right } \\
\text { side }\end{array}$ & $3 \times 5$ & Nodule \\
\hline 11. & $\begin{array}{l}\text { Singh et al. } \\
\text { [14] }\end{array}$ & 2014 & $1 / 3$ & 70 & M & $\begin{array}{c}\text { Canthus of left } \\
\text { eye }\end{array}$ & $2.5 \times 2$ & Nodule \\
\hline 12. & Present study & 2016 & 1 & 65 & M & Nose & $3 \times 4$ & $\begin{array}{c}\text { Ulceroproliferative } \\
\text { nodule }\end{array}$ \\
\hline & Total & & 13 & & & & & \\
\hline
\end{tabular}

The lumina may be filled with a colloidal substance or with an amorphous granular material, but the secretory activity of the cells lining the lumina cannot be delineated even with histochemical methods [16]. Because of its favorable prognosis, it is extremely important to distinguish adenoid basal cell carcinoma from more malignant tumors with a similar histopathological picture; primary cutaneous cribriform apocrine carcinoma and cutaneous adenoid cystic carcinoma. The prognosis and outcomes differ greatly and a correct histological diagnosis is vital in the management of these cases. Primary cutaneous cribriform apocrine carcinoma is considered to be a rare low-grade non-encapsulated dermal tumor with a cribriform pattern and exhibits aggregations of pleomorphic neoplastic cells as opposed to the monomorphous appearance of
BCC, and arranged in solid nests and tubules. Cutaneous adenoid cystic carcinomas, which carries a recurrent and metastatic potential, are characterized by basaloid cells in cords and tubules with a cribriform pattern and few small cystic spaces containing mucinous material in the mid- to deep dermis [22]. A lack of connection to the overlying epidermis, peripheral palisading of the basaloid islands of cells and retraction artifact of the surrounding fibrous stroma excludes an adenoid BCC. The tumor has slow progression and metastases are found in only $0.5 \%$ of the cases. The biological behavior of BCC is usually benign and cure is almost always achieved by Mohs surgery, electic cauterization and curettage, cryotherapy, roentgen therapy, laser treatment, 5-fluoruracil, imiquimod, interferon alpha, photodynamic therapy. 
But it can result in considerable local destruction and disfigurement when treatment is neglected and inadequate. In our patient, the growth was removed by wide surgical excision, and no evidence of recurrence has been found during the follow-up period of 10 months. Adenoid BCC, an extremely rare histopathologic variant of BCC characterized by a specific histologic appearance and is being reported because of its extreme rarity and to contribute in the spectrum of basal cell carcinomas.

\section{References}

1. Weedon D (2010) Weedon's Skin Pathology, ( $3^{\text {rd }}$ edn), London Churchill Livingstone Elsevier, pp. 668-756.

2. Betti R, Bruscagin C, Inselvini E, Crosti C (1997) Basal cell carcinomas of covered and unusual site of the body. Int J Dermatol 36(7): 503-505.

3. Crowson A N (2006) Basal cell carcinoma: biology, morphology and clinical implications. Mod Pathol 19(2): 127-147.

4. Copcu E, Aktas A (2005) Simultaneous two organ metastases of the giant basal cell carcinoma of the skin. International Seminars in Surgical Oncology 2(1): 1 .

5. Niwa A, Pimentel E (2006) Basal cell carcinoma in unusual locations. An Bras Dermatol 81(3): 281-284.

6. Cohen B, Weiss G, Yin H (2006) Basal cell carcinoma (BCC) causing spinal cord compression. Dermatol Online J 6(1): 12.

7. Fresini A, Rossiello L, Severino BU, Del Prete M, Satriano RA (2007) Giant basal cell carcinoma. Skinmed 6(4): 204-205.

8. Kim SH, Ko WT, Suh MK, Lee JI (2008) A case of axillary adenoid basal cell carcinoma. Ann Dermatol 20(1): 22-25.

9. Mehta V, De A, Balachandran C (2009) Painful hemorrhagic nodule on the chin. J Pak Assoc Dermatol 19: 121-123.

10. Golda N, Wheeland RG, Thomas TL, Trout C (2009) Adenoid basal cell carcinoma simulating ameloblastoma. Dermatol Surg 35(9): 1410-1413.

11. Wani GM, Ahmad SM, Qayoom S, Khursheed B (2012) Neglected basal cell carcinoma in axilla. JIMA 44(1): 1-4.
12. Tambe SA, Ghate SS, Jerajani HR (2013) Adenoid type of basal cell carcinoma: rare histopathological variant at an unusual location. Indian J Dermatol 58(2): 159.

13. Jetley S, Jairajpuri ZS, Rana S, Talikoti MA (2013) Adenoid basal cell carcinoma and its mimics. Indian J Dermatol 58(3): 244.

14. Singh AK, Gupta L, Kumar A, Kalra N (2014) Rare variants of basal cell carcinomas: a case series of three cases. Sch J Med Case Rep 2(1): 11-13.

15. Kossard S, Epstein EH, Cerio R, Yu LL, Weedon D (2006) Basal cell carcinoma. In WHO Classification of tumors, Pathology and Genetics of Skin tumors. ( $1^{\text {st }}$ edn). LeBoit PE, Burg G, Weedon D, Sarasin A, (Eds.) Lyon: IARC-Press, p. 13-19.

16. Kirkham N (2005) Tumors and cysts of the epidermis. In Elder DE, Elenitsas R, Johnson BL, Murphy GF, (Eds.) Lever's Histopathology of the skin. ( $9^{\text {th }}$ edn). Lippincott Williams \& Wilkins, Philadelphia, USA, pp. 805-866.

17. Epstein EH, Shepard JA, Flotte TJ (2008) Case records of the Massachusetts General Hospital. Case 3-2008. An 80-year old woman with cutaneous basal cell carcinomas and cysts of the jaws. N Engl J Med 358(4): 393-401.

18. Puri N, Talwar A (2013) A clinicopathological study on basal cell carcinoma. Asian J Med Cli Sci 2: 38-40.

19. Scrivener Y, Grosshans E, Cribier B (2002) Variations of basal cell carcinoma according to gender, age, location and histopathological subtype. Br J Dermatol 147(1): 41-47.

20. Bastiaens MT, Hoefnagel JJ, Bruijn JA, Westendorp RG, Vermeer BJ, et al. (1998) Differences in age, site distribution, and sex between nodular and superficial basal cell carcinomas indicate different types of tumors. J Invest Dermatol 110(6): 880-884.

21. Van Zuuren EJ, Bastiaens MT, Posma AN, Bouwes Bavinck JN (2000) Basal cell carcinoma on the dorsum of hand: report of 11 cases. J Eur Acad Dermatol Venereol 14(4): 307-310.

22. Van Der Kwast Th H, Vuzevski VD, Ramaekers F, Bousema MT, Van Joost Th (1988) Primary cutaneous adenoid cystic carcinoma: case report, immunohistochemistry, and review of literature. British J Dermatol 118(4): 567-578.

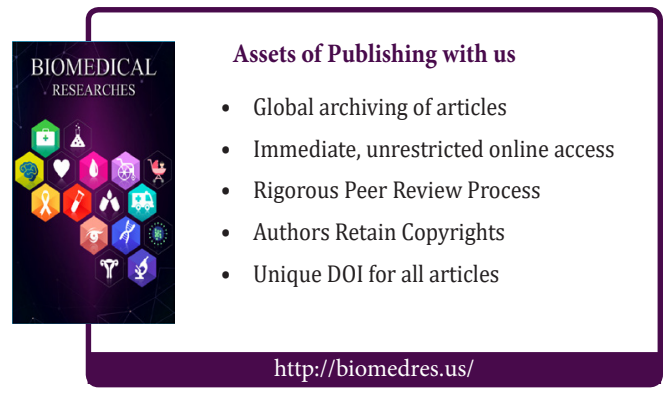

